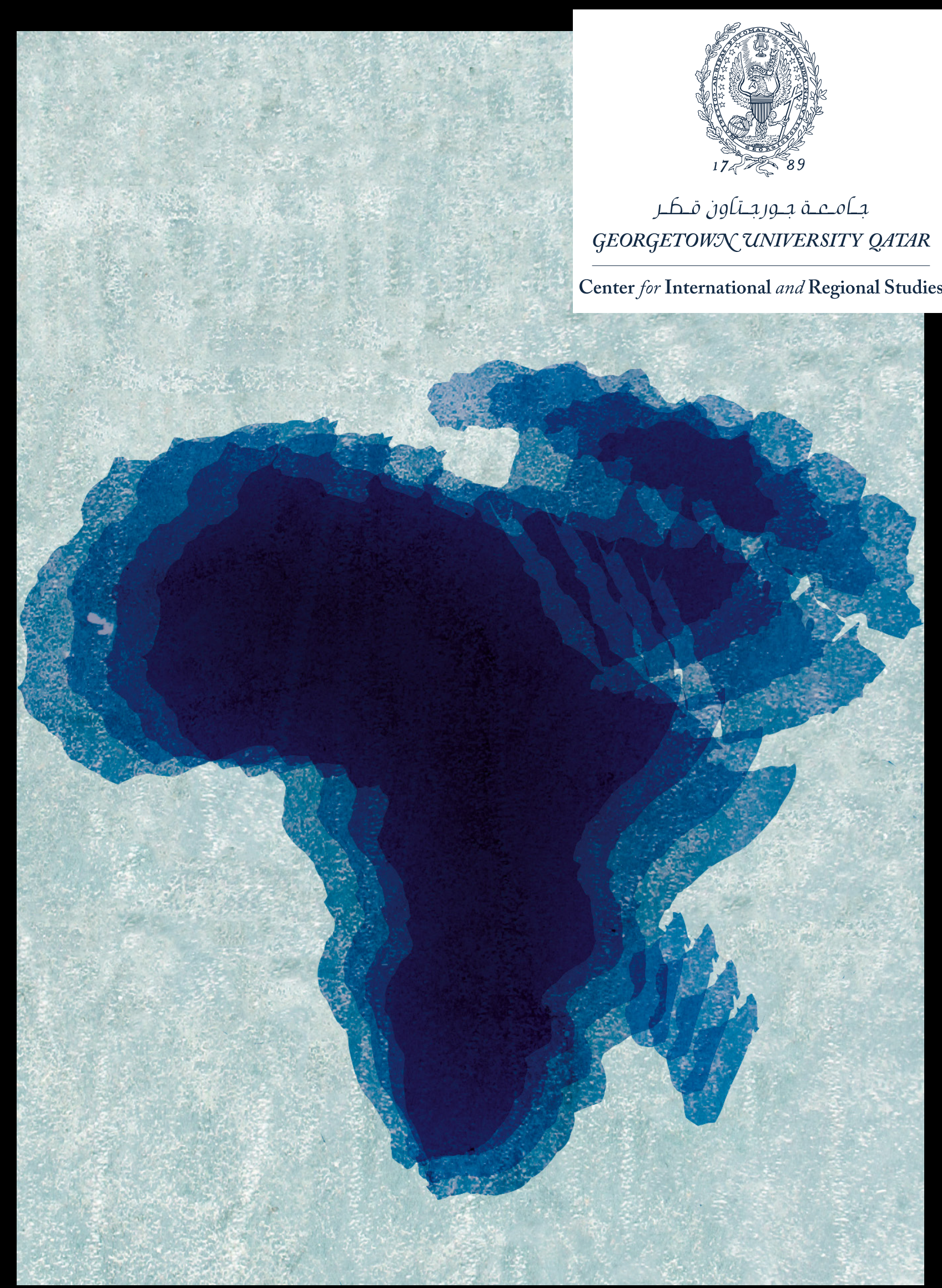

TRANSITIONAL JUSTICE IN THE MIDDLE EAST AND NORTH AFRICA 


\section{About the Georgetown University School of Foreign Service in Qatar}

Founded in 1789, Georgetown University is a student-centered international research university offering highly ranked undergraduate, graduate and professional programs preparing the next generation of global citizens to lead and make a positive impact in the world. The outstanding students, faculty, alumni and professionals of Georgetown are dedicated to real-world applications of research, scholarship, faith and service. For more information, please visit the website: www.georgetown.edu.

Founded in 1919, the Edmund A. Walsh School of Foreign Service (SFS) is a premier school of international affairs. At Georgetown's Washington, D.C. and Doha, Qatar campuses, SFS provides a rigorous education combining theory and practice while instilling the values of men and women in the service of others. At SFS-Qatar, students have the opportunity to major in Culture and Politics, International History, International Economics, and International Politics with the same curriculum as that available to students in Washington. For more information, please visit the website: qatar.sfs.georgetown.edu.

\section{About the Center for International and Regional Studies}

Established in 2005, the Center for International and Regional Studies at the Georgetown University School of Foreign Service in Qatar is a premier research institute devoted to the academic study of regional and international issues through dialogue and exchange of ideas, research and scholarship, and engagement with national and international scholars, opinion-makers, practitioners, and activists.

Guided by the principles of academic excellence, forward vision, and community engagement, the CIRS mission revolves around five principal goals:

- To provide a forum for scholarship and research on international and regional affairs

- To encourage in-depth examination and exchange of ideas

- To foster thoughtful dialogue among students, scholars, and practitioners of international affairs

- To facilitate the free flow of ideas and knowledge through publishing the products of its research, sponsoring conferences and seminars, and holding workshops designed to explore the complexities of the twenty-first century

- To engage in outreach activities with a wide range of local, regional, and international partners.

\section{About the Qatar Foundation for Education, Science and Community Development}

Qatar Foundation for Education, Science and Community Development (QF) is a private, non-profit organization that supports Qatar on its journey from a carbon economy to a knowledge economy. It does this by unlocking human potential for the benefit of not only Qatar, but the world. Founded in 1995 by HH the Father Emir Sheikh Hamad bin Khalifa Al Thani, Emir of Qatar, QF is chaired by Her Highness Sheikha Moza bint Nasser. QF carries out its mission via three strategic pillars: education, science and research, and community development. For more information, visit www.qf.org.qa

This publication is made possible by the generous support of Qatar Foundation for Education, Science and Community Development. 


\section{TRANSITIONAL JUSTICE IN THE MIDDLE EAST AND NORTH AFRICA}

WORKING GROUP SUMMARY REPORT

C 2017 Center for International and Regional Studies

Georgetown University in Qatar

Summary Report No. 16

ISSN 2227-1686 



\title{
TRANSITIONAL JUSTICE IN THE MIDDLE EAST AND NORTH AFRICA
}

\author{
WORKING GROUP SUMMARY REPORT
}

The protests that swept across parts of the Middle East beginning in December 2010 have had a dramatic impact on the political and social landscapes of the region. Rulers once thought largely immovable, from Tunisia's President Ben Ali to Egypt's Mubarak and Libya's Qaddafi, were unceremoniously ousted all within a matter of months of each other. To date, Egypt, Libya, Tunisia, and Yemen have seen their strongmen leaders removed, an ongoing civil war has engulfed Syria, conflict and violence have shaken Bahrain, and other countries in the region have experienced various levels of instability and expressions of public outrage.

While regimes may have fallen and authoritarian leaders deposed, these Middle Eastern countries are still undergoing processes of political transition and social change. What political formation ultimately emerges in each state will depend on its specific context and according to its own timetable. Whether new systems and structures of governance are profoundly different from those they replaced remains to be seen. However, what can be said with some assurance is that, region-wide, a common theme undergirding all of these struggles and the mass public protests that epitomize them has been the notion of citizens' rights to justice and dignity.

Societies that are in processes of transition from earlier systems of governance to new ones-particularly those that have overthrown one form of authoritarian rule - often contend with the thorny issue of reconciling with their past before they can effectively construct a new future. Experiences in other parts of the world where political movements have ousted dictatorships demonstrate that in order to build durable peace in post-conflict situations, citizens must be confident that there are legitimate structures that redress past grievances. The idea that the administration of justice during a period of political transition is critical to peace-building, referred to broadly as "transitional justice," emerged in the post-World War II era but gained significant momentum from the 1980s onwards.

Transitional justice encompasses the range of policies, practices, and mechanisms, both judicial and non-judicial, that post-conflict countries implement in order to reconcile with the legacy of their "evil" pasts, to address residual social and political grievances, reconstruct the state-citizen relationship, and ensure that emerging political processes have requisite legitimacy and public support. Amid a host of areas of engagement, the core functions of a transitional justice system are to end any ongoing human rights violations and prevent future ones, investigate past abuses, provide redress to victims and ensure that perpetrators are penalized, and create mechanisms for ensuring a durable peace through supporting national reconciliation. Explicit means by which transitional justice is implemented include trials and reparations, reinvigoration of the rule of law, establishment of truth and reconciliation tribunals, and institutional reform, particularly of the security sector.

Transitional justice has received significant scholarly attention in many other parts of the world, focusing on authoritarian regimes moving toward democracy, and there is a rich body of literature on the topic. While there has been limited academic exploration of transitional justice in relation to the Middle East, recent events have reinvigorated interest in the topic. Social, economic, and political justice were key themes raised by protestors during the uprisings across the Middle East. Several Middle Eastern countries have placed the issue on their national agendas, and have launched transitional justice mechanisms, consultation processes, and assorted areas of engagement. An examination of transitional justice within the context of the Middle East is both timely and necessary, and can contribute significantly to the existing body of scholarship on the subject.

In line with this, CIRS launched a multi-disciplinary research initiative to examine unfolding experiences of transitional justice across the Middle East in the post-uprising era, with original research chapters published in an edited volume titled, Transitional Justice in the Middle East (Oxford University Press/Hurst, 2016). 


\section{TRANSITIONAL JUSTICE IN THE MIDDLE EAST AND NORTH AFRICA}

\section{WORKING GROUP PARTICIPANTS AND CONTRIBUTORS}

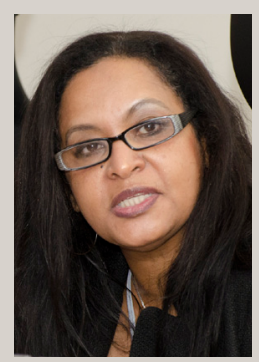

Rogaia Abusharaf

Georgetown University in Qatar

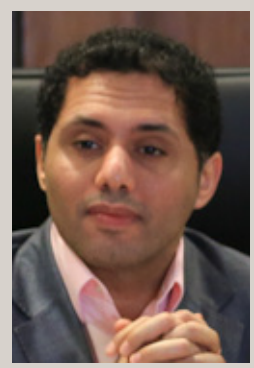

Omar Ashour

University of Exeter

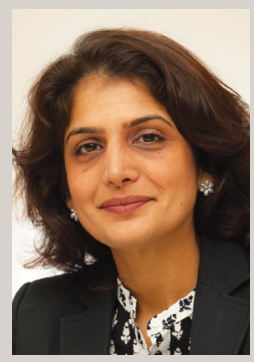

Zahra Babar

CIRS, Georgetown University in Qatar
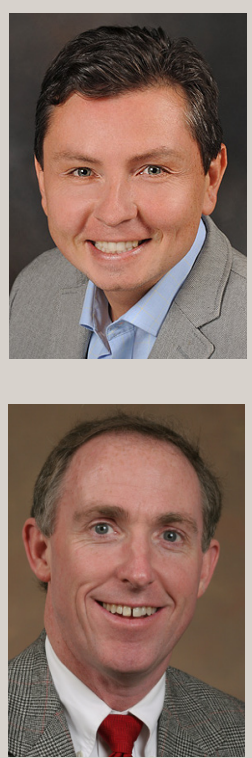

Terry C. Coonan

Florida State University

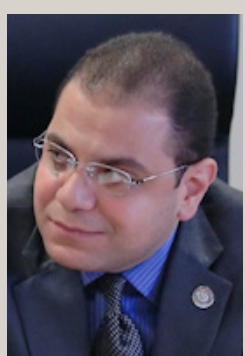

Mohamed Arafa

Alexandria University, Cairo University

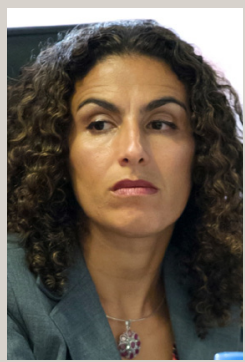

Sahar Aziz

Texas A\&M University

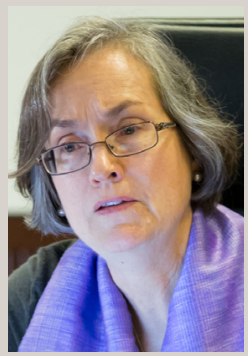

Judy Barsalou

El-Hibri Foundation, retired

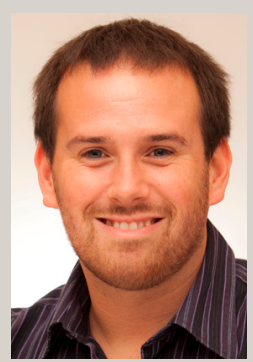

Matthew Buehler

CIRS, Georgetown University in Qatar

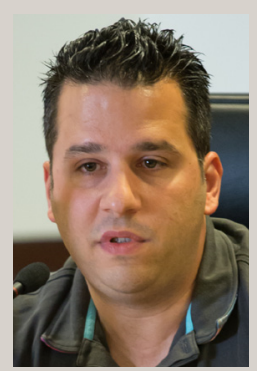

Thomas DeGeorges

American University of Sharjah 


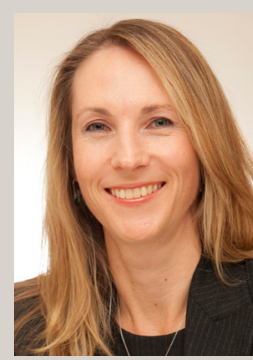

Nerida Child Dimasi

CIRS, Georgetown University in Qatar
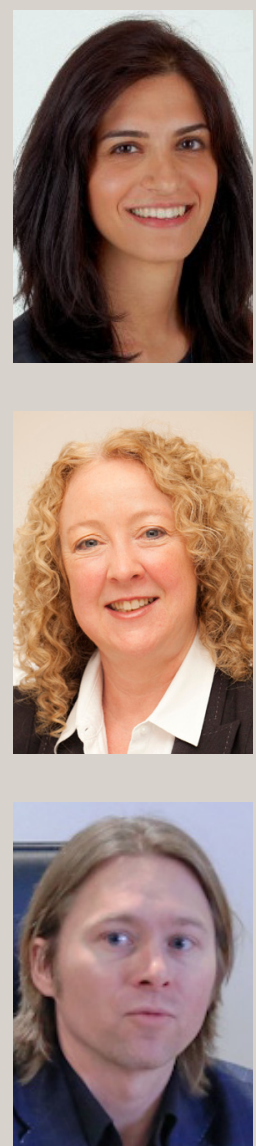

Sune Haugbølle

Roskilde University

CIRS, Georgetown University in Qatar

Elham Fakhro

Georgetown University in Qatar

\section{Barb Gillis}

$$
\text { Roskilde University }
$$

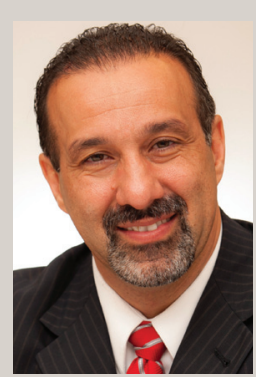

Mehran Kamrava

CIRS, Georgetown University in Qatar

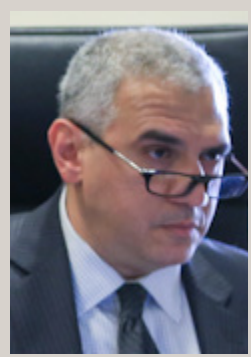

Mohammad Fadel

University of Toronto

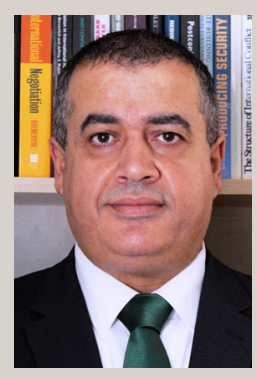

Ibrahim Fraihat

Doha Institute for Graduate Studies

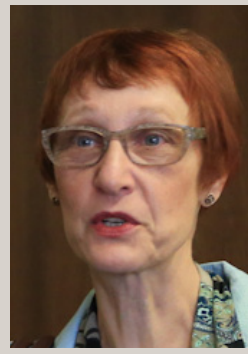

Doris H. Gray

Al Akhawayn University

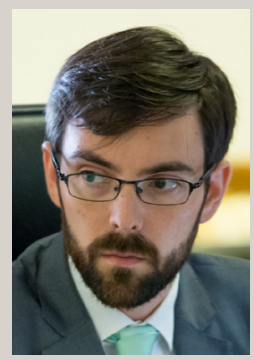

Bill Hess

Brookings Doha Center

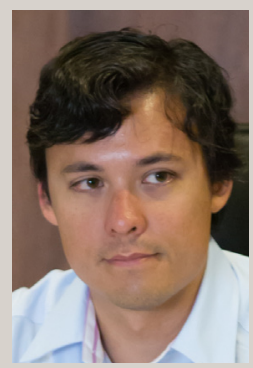

Christopher Lamont

University of Groningen 


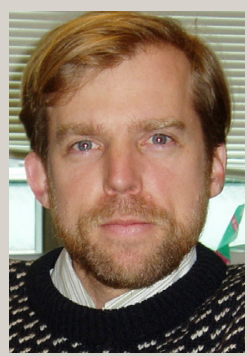

Clark Lombardi

University of Washington
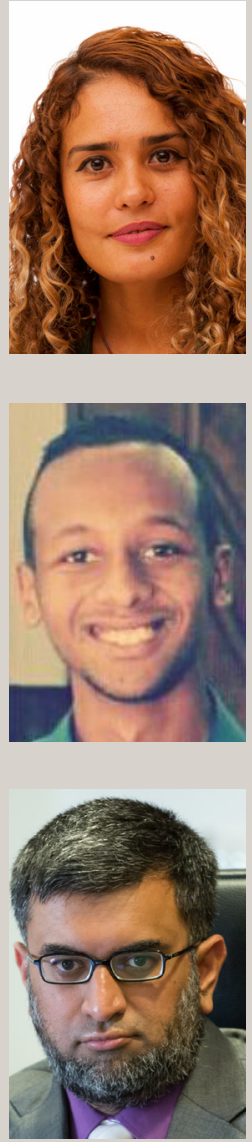

Moamer Qazafi

Georgetown University in Qatar

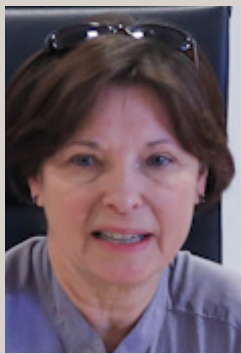

Susan Waltz

University of Michigan

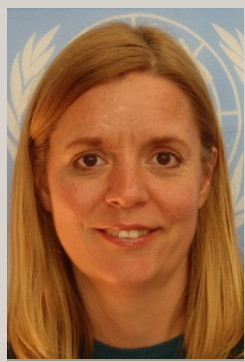

CIRS, Georgetown University

in Qatar

Sherif Mohyeldeen

Marieke Wierda

Leiden University

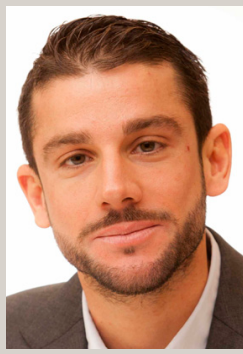

Dionysis Markakis

CIRS, Georgetown University in Qatar

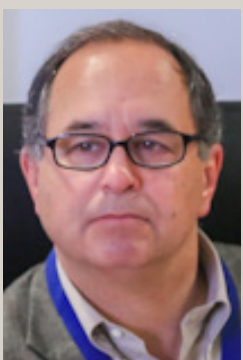

Joshua Mitchell

Georgetown University in Qatar

Egyptian Initiative for Personal Rights

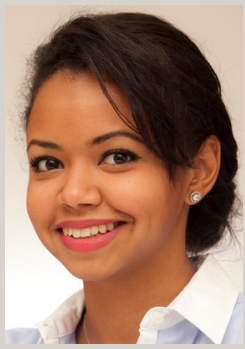

Dwaa Osman

CIRS, Georgetown University in Oatar

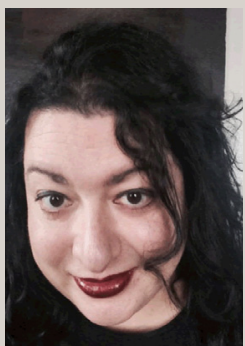

Chandra Lekha Sriram

University of East London

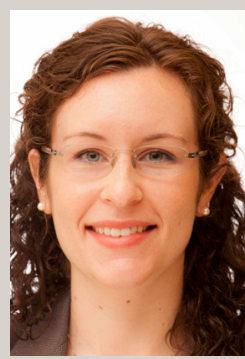

Elizabeth Wanucha

CIRS, Georgetown University in Qatar 


\section{TABLE OF CONTENTS \\ PAPER SYNOPSES}

1. Introduction: Transitional Justice in the MENA Region

Chandra Lekha Sriram, University of East London

\section{PART I: TRANSITIONAL JUSTICE: CHALLENGES, THEMES, AND SCOPE}

2. Transitional Justice in Comparative Perspective: Lessons for the Middle East

Chandra Lekha Sriram, University of East London

3. Linking Transitional Justice and Human Rights

Susan Waltz, University of Michigan

4. For the Sake of Peace or Justice? Truth, Accountability, and Amnesty in the Middle East

Ibrahim Fraihat, Doha Institute for Graduate Studies; and Bill Hess, Brookings Doha Center

5. The Scope and Boundaries of Transitional Justice in the Arab Spring

Christopher K. Lamont, University of Groningen

\section{PART II:TRANSITIONAL JUSTICE EXPERIENCES IN THE MENA REGION: COMPARATIVE LESSONS}

6. Reframing Gender Narratives Through Transitional Justice in the Maghreb

Doris H. Gray, Al Akbawayn University, and Terry C. Coonan, Florida State University

7. Martyrdom in North Africa Following the Arab Spring and the Process of Transitional Justice Thomas DeGeorges, American University of Sharjah

8. Political Exclusion and Transitional Justice: A Case Study of Libya

Mieczysław P. Boduszyński, Pomona College, and Marieke Wierda, Leiden University

9. Truth and Fact-Finding in the Arab Monarchies

Elham Fakhro, Georgetown University in Qatar

\section{PART III: KEY DIMENSIONS OF TRANSITIONAL JUSTICE: LESSONS FROM EGYPT}

10. "The Walls will not be Silent:" A Cautionary Tale about Transitional Justice and Collective Memory in Egypt Judy Barsalou, El-Hibri Foundation, retired

11. Theater or Transitional Justice: Reforming the Judiciary in Egypt

Sahar Aziz, Texas AEM University

12. Security Sector Reform and Transitional Justice After the Arab-Majority Uprisings: The Case of Egypt Omar Ashour, University of Exeter, and Sherif Mohyeldeen, Egyptian Initiative for Personal Rights 



\section{Introduction: Transitional Justice in the MENA Region Chandra Lekha Sriram}

The social and political uprisings in the Middle East and North Africa (MENA) region, designated the "Arab Spring" because the most visible ruptures appeared in the spring of 2011, drew global attention not only because they presented broad-based political protest against regimes that were long-entrenched, whether authoritarian or monarchical. They were landmark events because they led to the removal of several heads of state and prompted discussions of institutional reform. Notably, they also entailed a broad range of human rights claims, both those related to abuses by prior regimes of civil and political rights and bodily integrity, but also of socioeconomic rights. In short, they not only put transitional justice on the political agenda in a region of the world where it was seldom discussed (despite limited experiments in Morocco), but also put forward a broader view of transitional justice than that which has traditionally been implemented. However, many of these transitions have since stalled, leaving transitional justice similarly stalled, stunted, or manipulated for political ends. These phenomena are not unique to the MENA region, but rather experiences from elsewhere with limited or frozen transition may be informative to the region. Similarly, experiences in the MENA region should help to inform academic and policy debates in transitional justice.

The chapters in this volume, written largely by experts in the region, draw upon pre- and post-Arab Spring use of transitional justice mechanisms in a range of countries, including Algeria, Egypt, Tunisia, Yemen, Libya, Morocco, and Bahrain. While these countries have diverse histories, political institutions, and experiences with accountability, most have experienced non-transition, stalled transition, or political manipulation of transitional justice measures, highlighting the limits of such mechanisms. Their experiences should impel analysts to rethink presumptions about the purpose, operation, and scope of transitional justice not just in the MENA region, but also more generally.

Transitional justice is an ever-expanding field of academic study and practice which, broadly speaking, involves a range of measures to address past serious human rights abuses in the wake of transition, usually from authoritarian rule and/or violent conflict. While mechanisms of post-atrocity justice can be identified throughout history and more commonly after the Second World War, they became a more frequent element of political transition to a limited degree in Southern Europe in the late 1970s, and more extensively through transitions in Central and South America in the 1980s and 1990s and the post-communist revolutions in Eastern Europe in the 1990s. While transitional justice was initially implemented largely in post-authoritarian societies, it has become increasingly common in countries emerging from internal and cross-border conflicts, and in countries with ongoing conflicts and limited democracy or democratization in parts of Asia, sub-Saharan Africa, and in the MENA region. While transitional justice mechanisms and scholarship have broadened significantly, particularly in relation to peace-building and development activities, and both the concept and execution of transitional justice have been challenged in academic literature and by grassroots actors, several core elements of transitional justice can be identified.

Transitional justice in the MENA region, like the transitions there, is far from complete and faces many of the challenges seen elsewhere in the world. Scholars and practitioners may glean some cautionary lessons from these experiences to date. Most notably, it is clear that pursuing transitional justice mechanisms is not very 
effective while transitions are frozen or incomplete, or countries have lapsed into new stages of violence and authoritarian rule. Even where transitions have proceeded somewhat more smoothly, transitional justice is still subject to political manipulation. And even where leaders have been replaced, transitions may stall because core elites, whether political, military, or institutional, remain embedded. Further, where transitional demands include socioeconomic reforms and equity, transitional justice processes have not accommodated these well. As many authors note, these incomplete accountability measures, alongside failed or incomplete reform, create risks for future instability or have enabled repressive institutions to endure.

Chandra Lekha Sriram is Professor of International Law and International Relations, as well as Director of the Centre on Human Rights in Conflict at the University of East London. She is currently undertaking a collaborative three-year project which examines the long-term impact of transitional justice measures on democratic institution-building. Her research interests include international law, human rights, rule of law, conflict prevention and resolution, peacebuilding, international criminal law, and post-atrocity justice. Her most recent publications include a co-authored textbook, War, Conflict, and Human Rights, 2nd ed. (Routledge, 2014) and a co-edited volume, Transitional Justice and Peacebuilding on the Ground: Victims and Ex-Combatants (Routledge, 2012), to which she also contributed a case-study chapter on Lebanon. Her 2008 monograph, Peace as Governance: Power-sharing, Armed Groups and Contemporary Peace Negotiations (Palgrave) included research in the Sudan. She earned her MA from the University of Chicago, a JD from the University of California, Berkeley, and her $\mathrm{PhD}$ from Princeton University. 


\section{Transitional Justice in Comparative Perspective: Lessons for the Middle East Chandra Lekha Sriram}

Transitional justice is a vast, amorphous, and seemingly ever-expanding field. The questions it addresses range from the specific, such as dealing with past atrocities, to broader questions of how to promote conflict prevention and resolution, peace-building, rule of law, democratization, traditional justice processes, and social and economic justice. Internationalized criminal justice and domestic accountability for abuses of prior regimes date back to the Nuremberg and Tokyo tribunals and beyond. However, the contemporary practice of what is now termed transitional justice is generally understood to begin with transitions in the Southern Cone in Latin America, notably the prosecutions of former members of the military junta in Argentina following its return to democracy in 1983. Rather than review the extensive literature and practice, this chapter will discuss lessons and gaps from some three decades of practice in comparative perspective. Drawing upon the author's previous research in Latin America, South Asia, and sub-Saharan Africa, and building upon her limited research in MENA countriesspecifically in Lebanon and Sudan - this chapter seeks to identify relevant lessons for relatively nascent efforts at transitional justice in the region. While the literature and practice of transitional justice is relatively expansive and rich, having developed quickly over the past thirty years, there remain many gaps, which scholars have sought to fill with both qualitative and quantitative research. However, despite this research, debates remain unresolved as to whether transitional justice has any effect at all on immediate goals, such as bringing perpetrators to justice, or more attenuated goals, such as democratization and improved human rights records.

This chapter argues that despite extensive research in transitional justice, there are significant gaps in knowledge. These gaps are clustered into four categories, with examples from around the world, with implications for countries in the Middle East and North Africa. These include: 1) How to assess impact? 2) Who is demanding transitional justice/what is the grassroots view? 3) Does the institutional design of transitional justice measures affect desired outcomes? 4) Should transitional justice measures be expanded, particularly to address questions of economic rights and/or harm? Within these four categories, this chapter seeks to address a range of important questions that should be considered by researchers, or by those seeking to create or assess transitional justice mechanisms. These include: What is the goal/what is transitional justice being invoked for? What are our benchmarks for success? Can we measure/assess them, and if so, how? Are the mechanisms proposed or used reasonably designed to address the goals enunciated for transitional justice, or could they conceivably be?

Often, decisions about the creation of transitional justice mechanisms, and the assessments and critiques which follow, fail to take these questions into consideration sufficiently. However, clearly identifying what we do and don't know, how we might fill informational gaps, and where we may have unrealistic expectations about what transitional justice can do, is more than academic. It is also a matter of contemporary policy and programming as actors in international organizations, bilateral development organizations, and national and international NGOs seek to develop knowledge-based policies in complex transitional situations. Thus, this chapter seeks both to identify those knowledge gaps and questions, and to draw out some lessons and implications from comparative research in a range of locations across the world.

First, however, a clarification is in order. Transitional justice is now the dominant term for a field of study and practice that can encompass prosecutions, commissions of inquiry, apologies, and many more processes to do 
with human rights abuses per se, as well as related activities such as rule of law and security sector promotion; and its expansion has been significant. However, the two words in the term are themselves vague or contestable, which matters because this affects how one defines the parameters of transitional justice. This, however, is something on which the voluminous literature has seldom ruminated, much less converged. First, the term transitional is problematic, because increasingly mechanisms have been introduced in countries that have not undergone a significant change (such as democratization, or war termination). Thus the International Criminal Court (ICC) has been utilized in the context of significant violent conflict and varying degrees of polity change, in countries such as Sudan, the Democratic Republic of Congo, and Libya. In Morocco, the creation of a truth commission took place without a significant change in the state or ruling elite, but rather was initiated by a new king replacing his father; the commission in Bahrain took place in the context of no political transition; in Egypt, the elite reshuffled rather than any revolutionary change occurring, and constraints on the judiciary limited justice and the possibility of a genuine transition.

It is unclear whether transitional justice must take place in the context of a transition, and if so, what features must define such a transition, and how one can ascertain that they were definitely present. This is particularly salient in the MENA region, where questions of accountability have been raised for some time, but have been framed as transitional justice in the wake of the Arab Spring uprisings. Further, the diversity of post-Arab Spring justice processes requires close attention, as in some instances leaders were removed and/or tried (Egypt and Tunisia), even as other key figures remained in power and used transitional justice processes not to signal transition but to control state-building processes. Further, in Tunisia, similar to many states globally, there was a debate over the appropriate temporal scope of any transitional justice efforts-for abuses during the uprising only, or for longer periods of time. In other states, the leaders endured but instituted some transitional justice mechanisms, as in Bahrain. And in others, uprisings were followed by violent conflict, with or without any justice mechanisms being invoked for human rights violations, such as in Syria or Libya.

The concept of justice is one that has been debated by political philosophers for millennia, but is often rather underdefined in the context of transitional justice. Must it mean prosecutions only, or other modes of judicial accountability? Or should it also entail forms of accountability such as truth-telling, apologies, and so on? Transitional justice processes have generally been treated as encompassing both judicial and non-judicial measures. However, there have been quite vigorous debates about the relative value of particular mechanisms as "justice," and in particular strong arguments regarding the place of non-judicial "traditional" justice, or memorialization. These debates may be further stretched by the idea that transitional justice can include memorialization through martyrdom (not ordinarily characterized as transitional justice) as in Algeria and Tunisia, or modes of accountability that can effectively generate vetting such as "political exclusion" in Tunisia and Libya. We may also need to query whether the term "justice" applies at all in the context of show trials, selective trials, and punitive vetting processes. 


\section{Linking Transitional Justice and Human Rights Susan Waltz}

It is often assumed that a primary purpose of transitional justice processes is to improve human rights, such that the two are inextricably entwined. I begin this chapter, though, with the proposition that such assumptions must be discarded, or at least set aside, if we are to consider the relationship between processes of transitional justice and any eventual impact on a state's human rights performance. Viewed abstractly, transitional justice is a neutral policy instrument; it is a political device that can be used for several purposes, some at odds with the others. Some elements of civil society may hope for an improvement in human rights, but political leaders endorsing or promoting the idea of transitional justice may simply want to mark a political moment or consolidate a regime transition-or punish rivals and seal away an unpalatable past. Transitional justice need not be linked to the modern concept of human rights, and indeed, scholars have referred back as far as ancient Greece to understand the workings of judicial processes intended to mark a political transition. In the contemporary period, transitional justice mechanisms have proliferated and have taken many forms, including lustration, truth commissions, trials, and reparations.

The multiple forms of transitional justice are one important factor responsible for differential effects on subsequent human rights practice, but not the only one. The motivation and capacity of those in power after a political transition also shape the outcome of transitional justice processes. Authorities can support a judicial process with sincere intention to reveal truths and prosecute wrongdoing, but alternatively they can simply go through the motions, hoping to placate domestic or international critics and move on. Even officials who are not committed to reform or enhancing human rights may find some merit in a process of transitional justice that distances them from their predecessors and weakens or eliminates political rivals. In sum, many different motivations may lead to endorsement of a transitional justice policy, and there are accordingly good reasons to be skeptical that the outcome will favor human rights.

With that sobering reminder and with a focus on the Middle East region, this chapter addresses four distinct but related concerns that require attention when considering the probability that a process of transitional justice will improve human rights outcomes. The first of these relates to the identification of rights that are likely to be affected by a transitional justice process. While human rights advocates and professionals might see this as a straightforward matter, given the development of human rights standards over the past fifty years, vast gaps between professional orientations and popular perceptions and emphases can lead to very different expectations about the impact of transitional justice processes. This is particularly important in the context of the Arab Spring uprisings, which in some countries were driven by concerns about economic injustice that do not perfectly align with a mainstream human rights framework. The first section deals with the question of which rights, and whose rights, are likely to be affected by a transitional justice process. The following sections address three additional challenges that complicate efforts to gauge the impact of transitional justice on a state's human rights performance. These include the difficulties of dismantling a culture of impunity that encourages those in positions of authority to regard themselves as above the law; the challenge of institutional reform in the judicial and security sectors; and the troublesome question of how to observe and potentially measure the extent of any change in human rights performance. 
To illustrate the nature of the challenges that may confound efforts to improve human rights and to observe meaningful changes, I draw on recent experiences from Morocco and Tunisia, and to a lesser extent Egypt. Defined broadly, there have been a surprising number of transitional justice initiatives in the Middle East over the past fifteen years. To date, however, Morocco is the only country in the region to have completed a robust transitional justice process, and it went through quite a number of phases spanning several years. From 20042005 onward, its Equity and Reconciliation Commission (Instance Equite et Reconciliation, IER) investigated some 20,000 cases of human rights abuse. Morocco's experience unfolded in the context of a royal transition, as Mohammed VI sought to consolidate his hold on the monarchy, but popular sentiments at the time were not unlike those that surfaced throughout the region a few years later to fuel the Arab Spring uprisings. In Egypt, of course, uprisings convulsed the country for several months in 2011, and a decision to try President Mubarak for corruption and ordering excessive force against demonstrators was taken swiftly, though three years later Mubarak and several of his associates were acquitted of most charges. In the meantime, Mubarak's successor, Mohammed Morsi, was arrested and awaits trial, and former military leader General Abdel Fattah el-Sisi has been elected president. Tunisia, on the other hand, is proceeding with efforts to carry out a transitional justice process. In December 2013, the National Constituent Assembly approved a comprehensive transitional justice law and within the year a newly established Truth and Dignity Commission began its work. But Tunisia has also seen important changes in its political landscape, including the 2014 resignation of the Islamist government and the subsequent election of elder statesman Beji Caid Essebsi as the country's president. How far the Truth and Dignity Commission will go in pursuing its broad mandate remains uncertain.

The very range of experiences with transitional justice within the region — and indeed, across the worldsignals the need for caution about predictions of either short-term or long-term outcomes in particular cases. This chapter focuses attention on four issues recurrent in discussions of transitional justice and human rights. Together they establish the fault lines of a human rights analysis and suggest benchmarks for evaluating the human rights impact of transitional justice initiatives.

Susan E. Waltz is Professor of Public Policy at the University of Michigan. She is also involved in Amnesty International, recently completing a term on the Board of Amnesty-USA and formerly having served as international chairperson of the AI's International Executive Committee. For many years Waltz's research focused on North African regional politics and the local human rights movement. More recently, her research concerns the historical origins of international human rights instruments and the political processes that produced them. Waltz is coauthor of the website Human Rights Advocacy and the History of International Human Rights Standards, an on-line textbook that provides a narrative and numerous resources about human rights standards and where they came from. Other publications include entries in The Wiley-Blackwell Encyclopedia of Globalization (2011) and the Encyclopedia of Human Rights (Oxford University Press, 2009). She received her PhD from the University of Denver. 


\section{For the Sake of Peace or Justice? Truth, Accountability, and Amnesty in the Middle East Ibrahim Fraihat and Bill Hess}

In the wake of the Arab Spring uprisings, Tunisia, Libya, and Yemen are grappling with how to respond to the human rights violations that their former dictators perpetrated during their decades in power. In such transitional contexts, the choice that governments have has often been presented as a binary one: to pursue either peace or justice. In this dichotomy, peace usually means stability and the absence of violence, or "negative peace;" this as opposed to broader national reconciliation and social harmony, which would constitute a "positive" peace. Justice, meanwhile, implies the prosecution — and potentially punishment—of human rights violators through a fair legal process. There has been an underlying assumption that these two goals are difficult, if not impossible, to realize simultaneously. Such a conclusion seems logical. If a government pursues justice for past crimes, those whom it prosecutes are unlikely to keep the peace; but if it takes a lax approach to holding human rights violators accountable in the hope of maintaining stability, victims are unlikely to see justice served. This chapter will examine whether this traditional peace versus justice dichotomy is a credible one in the Middle East.

To achieve peace or justice following extensive human rights abuses, governments often employ transitional justice mechanisms. Three of the most prominent mechanisms are granting amnesties, pursuing accountability, and undertaking truth-seeking efforts. The purpose of this chapter is to analyze how Middle East states have applied these three mechanisms, and whether their application has contributed to peace and justice. To do so, we first undertake a historical assessment of the most robust pre-Arab Spring examples of Middle East governments implementing each of these mechanisms. Our case studies are the amnesties that Algeria granted during 1995-2006, Iraq's pursuit of accountability following the 2003 American overthrow of Saddam Hussein, and Morocco's 2004-2005 truth commission. Based on these case studies, we make three interrelated arguments. First, we find that Middle East governments' use of amnesty, accountability, and truth-seeking has not made meaningful contributions to peace or justice. We argue that this is because the governments' implementation of singe-mechanism approaches in the purported pursuit of either peace or justice has instead perpetuated instability, injustice, or both. We argue further that this is not merely the result of ignorance or incompetence, but of Middle East governments using transitional justice mechanisms primarily to preserve or consolidate their power, not to increase peace or justice.

This chapter proceeds with a brief review of the debates surrounding amnesty, accountability, and truthseeking measures, and how they can contribute to peace and justice. We then consider how these debates relate to the Middle East, and examine the aforementioned case studies. Having drawn lessons from the experiences of Algeria, Iraq, and Morocco, we will apply them to the ongoing cases of Yemen, Libya, and Tunisia. Relying on a series of interviews conducted in the three countries in 2012 and 2013, we conclude with some observations about how the approach each has taken to transitional justice thus far has impacted on its political transition. We ultimately find that for amnesty, accountability, and truth-seeking to have a positive impact in the region, its governments will need to embrace more balanced, holistic transitional justice approaches to their pursuit of peace and justice.

The Middle East's contemporary experiences with transitional justice have both reinforced the lessons drawn from the historical cases and introduced new ones. Once again, states that attempt to pursue either peace through amnesty or justice through accountability, while ignoring the other, are suffering from conflict and 
continued injustices. When it is nations that get involved, however, it appears that, much like the domestic stakeholders, they tend to support approaches that will most benefit themselves and their allies, rather than seeking out the best long-term option for the state at large.

Peace and justice are by no means easy aspirations to realize, especially in the aftermath of civil conflict, regime change, or both. Transitional justice mechanisms like accountability efforts and amnesties can help, but not if they are applied in a completely imbalanced manner and merely to serve the interests of a regime or subset of stakeholders. The lack of accountable leadership and inclusive politics in the Middle East has allowed its regimes to pursue many supposedly altruistic policies that ultimately do not benefit, and sometimes even harm, their populations. Such has been the history of transitional justice in the Middle East. This continues to be the case after the Arab Spring, except in Tunisia, which provides a glimmer of hope. Tunisia's hard work is just getting started, but its inclusive approach and willingness to consider all its options patiently-rather than immediately pursuing only either accountability or amnesty—may give it a chance to enjoy the best of both.

Ibrahim Fraihat is an international conflict resolution professor at the Doha Institute for Graduate Studies, and affiliate scholar at Georgetown University in Qatar. He previously served as senior foreign policy fellow at the Brookings Institution, and taught conflict resolution at George Washington University and George Mason University. His latest book is Unfinished Revolutions: Yemen, Libya, and Tunisia after the Arab Spring (Yale University Press, 2016). Fraihat has published extensively on Middle East politics, with articles appearing in The New York Times, Los Angeles Times, the Financial Times, and the Christian Science Monitor, Foreign Affairs, Foreign Policy, Alhayat, on the CNN and Al Jazeera websites, and elsewhere. Fraihat received a doctorate in conflict analysis and resolution from George Mason University in 2006. He is the recipient of George Mason University's Distinguished Alumni Award (2014) for his achievements in the field of conflict resolution. Follow on Twitter@i_farihat.

Bill Hess is a senior research assistant at the Brookings Doha Center, where his work has focused on transitional justice, national dialogues, and Islamist politics in Yemen, Libya, and Tunisia following the Arab Spring. He received his M.A. in Middle East Studies from George Washington University in 2015, and his master's capstone, "Enemy Brothers: Conflict, Cooperation, and Communal Dynamics within Lebanon," analyzed the response of Lebanon's major political parties to the Syrian conflict. Hess also completed a specialization in Conflict and Conflict Resolution, focused on Lebanon, Hezbollah, and the Israeli-Palestinian conflict, and studied Arabic in Jordan and the West Bank. 


\section{The Scope and Boundaries of Transitional Justice in the Arab Spring Christopher K. Lamont}

Since the beginning of what has become popularly known as the Arab Spring, there has been a renewed interest in transitional justice in the Arab world among both scholars and practitioners. Prior to 2011, the Middle East and North Africa (MENA) region was largely absent from studies of transitional justice, despite the fact that the region witnessed no absence of violent conflict, political transitions, or even transitional justice mechanisms. Instead transitional justice, as a field of scholarship and practice, draws heavily upon the Latin American, subSaharan African, post-communist European, former Yugoslav, and Asian experiences. To be sure, when reflecting upon transitional justice demands in the Arab Middle East, it is important to be aware that our engagement with the Arab Spring is through the lens of a field that has not engaged on a sustained basis with Arab experiences. It also draws heavily upon international legal frameworks, such as international humanitarian law and international human rights law, which can be limiting in the sense that it underplays concepts of social justice deeply rooted in Islamic political thought; but also potentially illuminating as it can provide an insight into contestations over the ownership of justice among local domestic actors.

As a field of law, transitional justice has drawn upon a post-Second World War move toward the international and domestic prosecutions of systemic human rights violations and violations of the laws of armed conflict. Engagement with transitional justice on the part of political scientists, on the contrary, draws upon case studies from the aforementioned regions, to conceptualize transitional justice principally in two ways. It is either theorized as a by-product of domestically negotiated political transitions, with variations argued to correspond to the balance of power between incoming and outgoing elites, or points to international diffusion of norms and ideas to explain justice outcomes.

Transitional justice processes in states directly affected by the Arab Spring remain in their infancy, and therefore this contribution's focus will be on the negotiation of transitional justice in the MENA region in order to understand some of the most salient sites of contestation in transitional justice debates. It will reflect on the nature of transitional justice in the Arab world, by exploring how Tunisia in particular, and other Arab states more broadly, responded to demands for justice voiced by protesters in 2011. Because Tunisia is perhaps more advanced in its post-Arab Spring transitional justice process than other Arab states, this contribution will take Tunisia as a case study through which lessons for understanding transitional justice in the region can be derived. Fieldwork for this chapter was carried out over eleven fieldwork trips to Tunisia between 2012 and 2014. It will argue, in part, that contestations of legitimacy, and ownership of transitional justice processes, are products of the negotiated origins of transitional justice. Negotiation here is not defined exclusively as negotiation between outgoing and incoming elites, but rather negotiation among transitional elites and in some cases external actors, as to the targets, time frame, content, and scope of transitional justice. It is these negotiations among transitional elites over the boundaries and scope of transitional justice that highlight wider contestations over state identity.

This contribution illustrates that in the Arab world, transitional justice demands voiced by political actors constitute attempts to deal concurrently with the legacy of past abuses and advance (in many cases) hitherto marginalized political projects, which have the potential for radical transformation of political orders established 
decades ago. The transformative potential of transitional justice in the Arab context has resulted in contestations over the content and scope of justice measures, with political actors attempting to mold transitional justice policies in a manner that reflects their own preferred narratives of the past and visions of the future.

Transitional justice can recalibrate the trajectory of political transitions in two ways. The first is through its potential role in excluding political actors from the transitional process, through either criminal trials of former elites or the political exclusion of elites in the form of lustration and vetting legislation. The latter was used in Libya to remove from political life anyone who was deemed to have been a public official under Qaddafi. The second path through which transitional justice can recalibrate the trajectory of transition is through its symbolic function in recasting narratives of statehood and legitimacy, or through the construction of a shared usable past. I argue the concept of usable pasts is helpful in illuminating how transitional justice debates and processes have played out during Tunisia's contested political transition

Christopher K. Lamont is Assistant Professor of International Relations at the University of Groningen in the Netherlands. He is a researcher at the Tekijuku Commemoration Center at Osaka University, where he was also a Visiting Lecturer at the Osaka School of International Public Policy (2013-2014). His research interests include transitional justice, international humanitarian law, international human rights law, North Africa, and the former Yugoslavia.Lamont is author of Research Methods in International Relations (Sage,2014), and International Criminal Justice and the Politics of Compliance (Ashgate, 2010). He earned an MSc from the University of Edinburgh, and a $\mathrm{PhD}$ from the University of Glasgow. 


\section{Reframing Gender Narratives through Transitional Justice in the Maghreb Doris H. Gray and Terry C. Coonan}

In recent decades, the field of transitional justice has addressed how states that are moving from war to peace or from authoritarian rule to democracy can best come to terms with legacies of mass abuse. Truth commissions are an integral part of transitional justice processes that also include criminal justice, in the form of pursuing former perpetrators at various levels, reparations, financial, medical, psycho-social, and institutional reform. In isolation, these mechanisms are limited in their effectiveness, but as a combined effort they may lead to reconciliation, justice, forgiveness, and a rescuing of history. Commentators have noted that few truth commissions to date have adequately addressed gender, and in particular the full impact of systemic human rights violations suffered by women under authoritarian regimes. Tunisia, in its ongoing transition from authoritarian rule, is the latest of a number of states that must now confront this challenge.

This chapter focuses on one mechanism currently employed in the Tunisian transitional justice endeavorthat of its national truth commission, and in particular the role of women therein. The chapter examines the gender complexities of the transitional justice task facing Tunisia, and the need to incorporate fully the broader experiences of repression suffered by Tunisian women in the country's truth commission endeavor. The chapter is based on more than ninety personal interviews conducted from 2011 to 2014. Interviewees were selected based on dossiers collected by the Tunisian Ministry of Human Rights and Transitional Justice, human and women's rights organizations, and newly formed victim's rights associations. Effort was made to include women from various parts of the country, to avoid focusing only on the capital city of Tunis. The views presented are representative of women who were victims of state-sanctioned repression during the Ben Ali era, regardless of their particular political or religious views or their socioeconomic status.

Tunisia is the first Arab Muslim majority country thus far to embark on a genuine transitional justice process: after the overthrow of the regime of Zine el Abidine Ben Ali on January 14,2011, an event that sparked uprisings throughout North Africa and the Middle East. Since the Tunisian uprising, there have been a number of important milestones. Tunisia held its first free and democratic elections in October 2011, won by the Islamist Ennahda (Renaissance) Party. In December 2013, the National Constituent Assembly (NCA) passed the Draft Organic Law on the Organization of Transitional Justice, providing the roadmap by which justice and accountability would be pursued in Tunisia. In October 2014, Tunisia held its second free and democratic elections in which Ennahda lost the majority of votes and the more secular Nidaa Tunis party took the lead. Presidential elections were held a month later. The International Center for Transitional Justice (ICTJ), headquartered in New York, praised the transitional justice law as one that sets out a comprehensive approach for addressing past human rights abuses. In January 2014 the NCA adopted a new constitution, and in May 2014 the NCA approved all fifteen members of a Truth and Dignity Commission (Instance Verité et Dignité or IVD), which is tasked with accounting for almost six decades of human rights violations.

On June 9, 2014, Tunisia reached yet another milestone when it formally launched its Truth and Dignity Commission. The 2013 Draft Organic Law tasks the commission with addressing reparations, accountability, institutional reform, vetting, and national reconciliation. The law specifically calls for the creation of a Fund for the Dignity and Rehabilitation of Victims of Tyranny, and for special chambers with trained judges to deal with 
cases of human rights violations. Violations against women and children are at the core of issues to be addressed by the Truth and Dignity Commission.

These are milestones in a country that has no democratic tradition, a country that passed from French colonial rule to two dictatorships: first Habib Bourguiba (1959-87) and then Zine el Abedine Ben Ali (1987-2011), who deposed Bourguiba in a bloodless coup in 1987 and ruled until his own overthrow in 2011. Given the postuprising situations in neighboring Libya and also Egypt, Tunisia has no contemporary role model in the Arab Muslim world to follow, and therefore developments in this country are important for the wider MENA region.

Among the most hotly debated topics since the fall of the Ben Ali regime are national identity, and with that the status of women. The issue of women's rights is at the political frontline in post-revolution identity politics. Despite the apparent contradictions between Islamists and more secular feminist approaches, both sides share a common desire to recoup ownership of the women's rights agenda. The issue of Islam versus secularism framed the post-revolution public discourse, as well as the question of women's status, and subsequently became fully politicized. Two of the main justifications of the Ben Ali regime, and the reasons for continued Western support, were Tunisia's exemplary status of women's rights—unparalleled in the MENA region—and the fact that Islamists, successfully portrayed within and outside Tunisia as akin to terrorists, were either in jail or in exile. The Tunisian Personal Status Code of 1956 is one of the most progressive in the Arab world, and has served as an example for neighboring Algeria and Morocco.

Doris H. Gray is Associate Professor in the School of Humanities and Social Sciences at Al Akhawayn University in Ifrane. She has previously served as an Associate Lecturer at Florida State University. She is author of Beyond Feminism and Islamism: Gender and Equality in North Africa (IB Tauris, 2012), and has published in the International Journal for Transitional Justice (2013), Mediterranean Politics (2012), and Expressions Maghrébines (2012).

Terry C. Coonan is Executive Director of the Center for the Advancement of Human Rights at Florida State University, where he also serves as Associate Professor of Criminology, and Courtesy Professor of Law. Most recently, Coonan has worked on human trafficking in North Africa. He has previously worked at the US Department of Justice in the Executive Office of Immigration Review, he has litigated asylum and immigration cases across the US, and has worked on various UN human rights projects. Professor Coonan earned his JD from the University of Cincinnati. 


\section{Martyrdom in North Africa Following the Arab Spring and the Process of Transitional Justice Thomas DeGeorges}

This chapter addresses the ways in which martyrdom has been deployed as part of a transitional justice process in the North African countries of Algeria, Morocco, and Tunisia. It argues that although martyrdom has deep cultural roots in the region's past (often connected to the related Islamic archetype of exceptional "friends of God"), references to martyrdom by the modern nation-states in the MENA region have sought to reinforce the state's legitimacy during times of political transition. The success of such efforts, however, varies widely among the Maghreb countries. I will argue that a process of transitional justice that embeds the memory of martyrdom as an unalterable component of a country's political system, as in Algeria for example, via the creation of public spaces of memory and their repeated inclusion in public discourse, is a poor substitute for politics. In many ways, Algeria remains a bitterly divided society after the war of liberation (1954-62) and the period of civil unrest in the 1990s, because of the failures of a political system which overly venerates the dead instead of focusing on policies designed to improve the conditions of the living.

Morocco and Tunisia, however, have pursued more promising paths of reconciling societal divisionswhether colonial or post-colonial - by establishing truth commissions that recognize the sacrifices of victims of state violence without allowing martyrdom to overshadow other elements of the official historical narrative of the state. Although victims of injustice (usually at the hands of state institutions and actors) feature prominently in the historical narratives of all three countries, Morocco and Tunisia have exhibited a willingness to experiment with various transitional justice bodies in a way that resolves political divisions, rather than exacerbates them. This is in contrast to Algeria.

The concept of martyrdom may seem to have little utility initially in a transitional justice context, especially given the myriad ways in which it may be defined. In this chapter, martyrdom will be used to refer to persons who are victims of political violence. Often, this violence will result in the confirmed death of the victim as a direct result of security forces. However, it will also be employed to refer to individuals who were victimized by unknown actors, as well as those victims whose fate remains uncertain due to lack of forensic evidence.

Analyzing post-revolutionary Tunisia, it is interesting that the initial uprising that ousted Ben Ali from power was focused around the concept of martyrdom. The seminal event that is often associated with igniting the social and economic demands of the Tunisian people was the dramatic suicide of the Sidi Bou Zid fruit seller, Mohammed Bouazizi. This desperate act was caught on cellphones and rapidly went viral within the region, acting as a symbol of the regime's injustice toward the "ordinary man." Following his act of self-immolation, Bouazizi survived for a while longer in the burns unit of a Tunisian hospital. He was visited there by Ben Ali himself, thus elevating Bouazizi's status (albeit mute) as an interlocutor of sorts with the regime. Following Bouazizi's death and the subsequent flight of Ben Ali and his family to Saudi Arabia, it might be expected that the young man's death would continue to inspire Tunisians. Instead, Bouazizi's sacrifice has been overshadowed by his family's controversial decision to leave Sidi Bou Zid to move to a wealthy suburb of the capital, Tunis. More recently, the deaths of Tunisian political leaders and soldiers have captivated public imagination. The killings of 
leftist political leaders Chokri Belaid and Mohammed Brahmi in 2013 sparked large street protests against the ruling government officials, and ultimately led to the resignation of two separate governments led by the Islamist Ennahda party.

A challenge often encountered when studying and documenting martyrdom is, of course, how closely and accurately can the martyr's life be portrayed when, by definition, the last stage (death) eludes our experience. Given this limitation, to what extent can any post factum analysis or study of martyrdom provide answers to the questions of a martyr's ultimate intent and purpose? Didier Fassin, in his analysis of international aid organizations' documentation of trauma and martyrdom among Palestinian populations, offers a convincing exposition of how victim experience and testimony have been rendered by both conflict survivors and the bureaucratic institutions that aid them. Of most relevance here is Fassin's contention that the experiences of victims or martyrs of violence in conflict societies are interpreted and defined by bureaucratic institutions that are inherently political, and which use first hand testimony to support broader narratives of victim experience based in compassion or injustice. During the twentieth century, Fassin argues that the increasing brutality of warfare created unprecedented numbers of first-hand witnesses, while the growing bureaucratization of society forced the "third parties" involved in assisting them to develop procedures and codes of conduct when documenting state criminality.

It is the way that martyrdom is analyzed by external, bureaucratic actors (via the procedures of truth commissions) that makes its contribution to transitional justice so important. By quantifying the number of martyrs and defining their individual experiences of victimhood, these truth commissions begin the transitional justice process of establishing a "new social consensus." Given such high expectations in post-conflict societies, and the lack of "shared notions" regarding societal truths mentioned above, such commissions have set the stage for vastly different interpretations of the meaning and political significance of martyrdom, for future generations in the three countries under consideration.

Thomas DeGeorges was Assistant Professor of International Studies at the American University of Sharjah from 2007-2014. His research areas include social policies designed to accommodate North African colonial veterans and former Algerian mujahideen and the politics of memory in Kuwait in the aftermath of the Gulf War. In addition to his academic duties, DeGeorges served as Director of the American Research Center in Tunisia from 2010-2011. His publications include articles in The Journal of North African Studies $(2009,2013)$ and a chapter on Algerian and Tunisian soldiers during and after the World Wars in The World in World Wars: Experiences, Perceptions and Perspectives from Africa and Asia (Leiden, 2010). DeGeorges earned his PhD from Harvard University. 


\section{Political Exclusion and Transitional Justice: A Case Study of Libya Mieczysław P. Boduszyński and Marieke Wierda}

The Libyan revolution of 2011 initially generated much hope. When Qaddafi, who ruled the country ruthlessly and erratically for forty-two years, was toppled by a broad coalition of rebels backed by NATO, Libyans had a rare opportunity to rebuild their state in accordance with the appeals to justice ('adala), freedom (burriyya), and dignity (karaama), which had animated the revolution.

The chaos that characterized Libya at the end of 2016 stands in stark contrast to the optimism that accompanied its transition early on. In many ways, post-Qaddafi Libya appeared to be a country ripe for transitional justice. Unlike the revolutions in Tunisia and Egypt, where there was some kind of accommodation with remnants of the former regime, Libya's revolution was much more far-reaching, and thus the prospects for real accountability seemed greater since Libya's new rulers did not have to enter into any compromising "pacts" with former rulers. The previous regime and its affiliated structures fully collapsed. Many former regime figures were taken into custody. Moreover, the coalition that came together to fight Qaddafi was unusually broad and unified, compared, for example, to Syria's factitious opposition. Such unity, as well as Libya's rich traditions of mediation and reconciliation between tribes, could arguably have provided the basis for genuine transitional justice and post-conflict reconciliation. Instead, the country has succumbed to ever increasing levels of violence. The justice that exists is most often meted out in the form of extra-judicial violence and revenge against those deemed by revolutionary brigades to be collaborators of the former regime.

In this chapter, we focus on a highly exclusionary vetting measure passed by the transitional Libyan parliament in 2013. Ironically, those subjected to this measure have not been Qaddafi henchmen, but revolutionary stalwarts. Less than two years after the fall of Qaddafi, many of the revolution's main protagonists found themselves excluded from political life owing to a draconian measure called the Political Isolation Law (PIL). The PIL excluded a number of the most prominent leaders of the uprising, among them Mahmud Jibril, Mustafa AbdelJalil, and Mohamed Magarief, all of whom once held senior positions in Qaddafi's regime but became key leaders in the National Transitional Council (NTC). Indeed, the paradox of transitional justice in Libya is that while revolutionary leaders and others have been excluded from public life, little else in terms of transitional justice has been delivered, either in the form of verdicts against senior former regime figures in custody or reparations measures for victims.

Why has the struggle for a broad and inclusive justice failed in Libya, replaced instead by a harsh form of political exclusion? This chapter situates the PIL in a broader political — and now violent—struggle for legitimacy and power in the new Libya. The Libyan case provides a cautionary tale in terms of the dangers of pursuing transitional justice in the form of retributive purges without parallel measures that could heal divisions and promote reconciliation, such as truth telling or reparations for victims.

We proceed as follows. The first section places the Libyan PIL in context by defining and analyzing the trade-offs inherent in vetting, lustration, exclusion, and purging mechanisms as forms of transitional justice, with comparative examples from other transitional and post-conflict states. This section also reviews some of the theories that have been put forward to explain the political determinants of various transitional justice 
mechanisms. Finally, it outlines the provisions of the Libyan PIL. The third section outlines the legacies of the past that Libyans face in their pursuit of justice, showing how institutional collapse and weak statehood have created a climate of impunity and intense competition for resources and power among Libya's ubiquitous extra-state militias, and describes existing efforts to deal with these legacies through nascent transitional justice mechanisms. The fourth section argues that a climate of victor's justice and revolutionary legitimacy has prevailed in Libya, further complicating the delivery of justice by the extremely weak state. It shows, moreover, how the PIL rose to prominence in the context of intense post-Qaddafi battles between different political camps and notions of legitimacy and has contributed to the chaos that engulfs Libya three years after Qaddafi's demise. The conclusions consider the consequences of the law to date, and argue that the zero-sum politics of exclusion reflected in PIL hinder any kind of settlement, reconciliation, and lasting peace in post-Qaddafi Libya.

Mieczysław P. Boduszyński is Assistant Professor of Politics and International Relations at Pomona College in California. His publications include articles on Libya in the Georgetown Journal of International Affairs and Journal of Democracy. He has published a number of articles on Balkan politics and international justice, and authored the book Regime Change in the Yugoslav Successor States: Divergent Paths toward a New Europe (Johns Hopkins University Press, 2010). He earned his MA and PhD from the University of California, Berkeley. Before teaching at Pomona, he worked as a US diplomat for nine years, most recently serving as a Public Affairs Officer in Libya. He also served in a variety of positions at US Embassies in Albania, Kosovo, Japan, and Egypt.

Marieke Wierda is a PhD candidate at the Grotius Center for International Legal Studies at Leiden University, on leave from her post as the Transitional Justice Advisor to the UN Support Mission in Libya. She previously worked for ten years with the International Center for Transitional Justice, where she worked extensively with transitional justice in Sierra Leone, Uganda, Lebanon, and Afghanistan. She is the author of many book chapters and articles on international criminal law and transitional justice, including a book on International Criminal Evidence, co-authored with Judge Richard May (Martinus Nijhoff, 2013). Wierda earned her LLB from University of Edinburgh, and her LLM from New York University. 


\section{Truth and Fact-Finding in the Arab Monarchies Elham Fakhro}

During periods of post-conflict transition, incoming governments and civil society groups often prioritize the pursuit of accountability and restitution for crimes committed by former regimes. During such periods of political transition, efforts at establishing accountability typically fell within the jurisdiction of national criminal justice systems, which took up the task of enforcing retributive or restorative justice. Today, local transitional justice practices are increasingly shaped by two contemporary and international trends. The first is the rise of an international human rights movement, which claims to promote a value-based system of rights independent from the framework of formal politics. Rather than drive change through traditional avenues of politics or through the language of ideology, this movement emphasizes the creation of legal and institutional mechanisms to improve the rule of law, good governance, and individual rights. Within post-conflict settings, this trend toward institutional creation has contributed to a growth in the number of specialized judicial and quasi-judicial bodies, including specialized courts, tribunals, and fact-finding bodies. A second trend shaping the contemporary transitional justice movement is the tendency toward the replication of human rights institutions across state borders, or "institutional borrowing." Both trends have had a visible effect in driving the establishment of truth commissions across national borders, as specialized mechanisms able to reveal the truth about past crimes.

Established mainly in Latin America to uncover the truth about past abuses during the third wave of democratization, truth commissions are increasingly being created within states undergoing different forms of transition, by governments seeking to achieve a diverse range of aims including democratization, accountability and restorative justice. The dual trends of institutionalization and globalization within the field of transitional justice has influenced the behavior of governments and political activists in Arab states. In Morocco, leftist opponents of the regime launched a campaign in 1999 calling on King Mohammed VI to create a truth commission to reveal the truth about forced disappearances taking place between the 1960s and 1980s, and establish compensation and accountability for disappearances. Eager to improve the monarchy's image abroad and build new alliances with its leftist opponents against the rising threat of radical Islamism, King Mohammed VI launched a truth and reconciliation commission in 2004, declaring it part of a broader process of political liberalization and reform in the state. Inspired by the campaign in Morocco, political activists in Bahrain launched a similar campaign in the year 2000, to pressurize the leadership to create a truth commission to investigate claims of torture taking place during a twenty-five-year period of unrest between 1975 and 2000. As Arab Spring-inspired protests erupted in 2011, the monarchy faced renewed calls by opposition activists and Bahrain's international allies to establish accountability for the deaths of protesters that year. In this context, King Hamad bin Isa Al Khalifa created the Bahrain Independent Commission of Inquiry, mandated to reveal the truth about events taking place during a two-month period of unrest.

The chapter investigates several themes. It examines the effectiveness of truth commissions that operate outside democratic transitions, the context for which they were originally created, relying on two examples from the Arab world. It questions the effectiveness of commissions operating in such non-democratic contexts, and the importance of the broader political environment in shaping their efficacy. It also questions the broader aims and purposes of these institutions, particularly in view of the absence of internationally-agreed criteria for determining their objectives and assessing their outcomes. The chapter analyzes two case studies: Morocco's Equity and Reconciliation Commission (IER) and Bahrain's Independent Commission of Inquiry to offer some insights into these questions. 
The research provides insight into the factors affecting the operation and long-term impact of fact-finding bodies in Morocco and Bahrain, and relies on these examples to draw conclusions about broader challenges in the field. It reveals that as with other fact-finding bodies created in the aftermath of democratic transitions, the commissions established in Bahrain and Morocco operated within the context of political sensitivities and sometimes in the presence of outright prohibitions in their mandates preventing them from identifying individual responsibility for past abuses. As a result, their investigations were limited to establishing general patterns of past abuse. While these commissions would no doubt have been more effective had they been granted the ability to reveal the identities of the perpetrators of abuse, the acceptance of their narratives by the heads of state in Morocco and Bahrain, and implicit admission of governmental responsibility, also provides an important break with the past in states otherwise characterized by years of denial of past abuses. The distribution of reparations, particularly in Morocco, also had symbolic and practical significance. While both commissions emerged as remarkably successful in detailing general patterns of past abuses, their ability to act as catalysts for lasting reforms was successful only in instances where the conflict in question had come to an end, and where governments and opposition leaders had reached a political settlement. Within mainland Morocco, the creation of the Equity and Reconciliation Commission came about in the aftermath of a broader process of reconciliation between the government and opposition actors, and following the establishment of a series of mechanisms intended to promote reform, notably the Advisory Council on Human Rights (CCDH) and the Independent Arbitration Commission (IAC). The inclusion of former regime opponents within the commission was key in allowing it to gain symbolic significance and mark a new era of improved human rights practices in the state. Amidst a broader process of reconciliation, the country's human rights record did witness a substantial improvement from the past. This is not the case with Bahrain or Western Sahara, where no settlement was reached between opposition actors and the government.

Examining the impact of truth commissions operating under monarchies, and in the absence of democratic transitions, raises broader questions in the field of transitional justice. In the absence of objective or internationally agreed criteria for what constitutes a transition, or how these commissions should be assessed, how much should be expected from these bodies? Should they be understood as vehicles designed only to examine past abuses, or should they also be expected to deliver a basket of desirable aims designed to strengthen the rule of law, or promote democracy? As these institutions continue to proliferate across the globe, scholars and practitioners will need to take steps to improve assessment of their impact across these different settings, and identify their limitations within these contexts. What is particularly evident is that an institutional form cannot act as a substitute for a political process, particularly when so much of the work of these commissions is both shaped by, and in response to, a set of local political circumstances.

Elham Fakhro is a doctoral candidate at the Centre for Socio-Legal Studies, University of Oxford. She previously acted as a Researcher with organizations including Georgetown University School of Foreign Service in Qatar, the International Institute for Strategic Studies, and the Bahrain Independent Commission of Inquiry. Fakhro has also acted as a Lecturer in International Human Rights Law at the University of Bahrain, and completed a Masters in Law at Harvard University. Her research interests include law and society, conflict, and security.

18 Media and Politics in the Wake of the Arab Uprisings | Summary Report 


\section{0. "The Walls Will Not Be Silent:" A Cautionary Tale about Transitional Justice and Collective Memory in Egypt Judy Barsalou}

The application of transitional justice entered a new phase with the wave of uprisings that swept through the Arab world starting in 2010. In a region where authoritarian regimes have long prevailed and little justice has been available for their victims, the uprisings raise questions regarding Arab expectations about justice and accountability in politically dynamic settings, including when or how to implement transitional justice when the nature or extent of the transition is not yet clear. This chapter explores two primary questions: following the removal of President Hosni Mubarak in February 2011, to what extent has transitional justice been undertaken in post-Mubarak Egypt? And how have collective memory processes affected struggles to define the country? It examines the intellectual underpinnings and contested understandings of the goals of transitional justice, as viewed through the blurry lens of the Egyptian "revolution," and it shares insights from fieldwork conducted in Egypt between November 2011 and March 2012, which focused on the expectations and hopes articulated by some Egyptians during the first year following Mubarak's removal.

There are three lessons from this experience relevant to Egypt and beyond. First, as transitional justice becomes increasingly established internationally, it risks being regarded as a set of technical "fixes," as experts arrive to advise transitional governments and civil society activists on its different elements. Clearly, the situation was complicated by Egypt's stalled or blocked transition to democracy, and by differing views about the goals of transitional justice held by those who desired deep change. Regarding the latter, for some the main goal of the uprising was to achieve social justice, defined by improving public services and raising the standard of living of the poor.Democracy was less important. Illustrative of this perspective were views expressed by Nasserites (proponents of the nationalist ideology articulated by President Gamal Abdul Nasser, himself a leader of an authoritarian regime established by military coup) at a meeting organized by the Ibn Khaldun Center for Development Studies. They argued that Nasser's government had achieved transitional justice through land reform, implying that a post-Mubarak government operating under unreformed security and military services could do the same. For these young Egyptians, social justice trumped democracy, and the point of transitional justice was to achieve the former but not necessarily the latter. Aside from disagreement about the goals and application of transitional justice, this issue underscores a significant challenge for transitional justice: it generates expectations that it can and should address the socioeconomic demands of victims whose loss of human dignity is rooted in inequality and poverty. But transitional justice theory and practice specifies no clear guidelines to satisfy such expectations, and its track record of promoting social justice is poor.

Second, evolving conditions in Egypt underscore the need for in-depth research about how Egyptians view transitional justice. While preliminary findings suggest that many held strong values and well-reasoned expectations relating to justice and accountability in post-Mubarak Egypt, further research based on a national sample is essential, particularly because the unstable situation in Egypt since then may have caused many who participated in our survey to reconsider their views. International transitional justice experts should be cautious if they presume to know what Egyptians want, especially in view of preliminary findings from that survey regarding attitudes about seeking remedies through international justice mechanisms if Egyptian courts fall short. Even then, many of our respondents were skeptical that it is legitimate to seek justice outside Egypt if it is not accessible 
locally. Some interviewees used strong language to denounce any who might embrace this course of action. Since these attitudes were expressed in the first year following the uprising, Egyptians' negative views about international transitional justice may have intensified, spurred by the filing of a complaint at the International Criminal Court by the now-banned Muslim Brotherhood.

Third, access to digital technologies and the use of social media have radically democratized and expanded the reach of contributions made by ordinary people to collective memory processes. In Egypt, approximately a third of the population has regular access to the internet, while most now have mobile phones. Rising levels of basic literacy and the spread of the 24-hour news cycle have improved access to information and contributed to the sense that the whole world is watching. Egypt has the highest number of Facebook users (sixteen million) in the Arab region and is ranked seventeenth worldwide. In this context, both managing conflict relating to memorialization and shaping it as a tool to promote transitional justice and social reconstruction have become more challenging. Yet, these developments were not reflected in the agendas of transitional justice conferences held in Cairo in 2011 and 2012. They focused on instigating criminal accountability, recovering looted assets, implementing lustration, and achieving security sector reforms-all vitally important, to be sure-but not on managing memorialization. The irony is that such processes were not in easy reach, given the strong grip of the "deep state," whereas memorials crafted by ordinary people in honor of victims and shaping collective memory about the past were immediately visible in the streets surrounding the conference halls. The failure to recognize the role that memorialization plays in influencing collective memory represents both a risk to future governments vulnerable to ongoing unrest, and a lost opportunity to promote social reconstruction through critical but inclusive narrations of the past.

Where does that leave transitional justice in Egypt? Clearly, it is stalled for the time being, especially since a military coup swept away the Morsi government and instituted President el-Sisi. Under the circumstances, it is difficult to imagine progress on transitional justice, despite the existence of a largely inactive Ministry of Transitional Justice and National Reconciliation. But the story of Egypt's uprising has not yet ended. Memories of the 25 January Revolution lie just below the surface, and expectations of a better life are just around the corner.

Judy Barsalou Judy Barsalou retired as President of the El-Hibri Foundation in 2014. She previously served as a visiting scholar at the American University in Cairo, where she conducted research on Egyptian views of justice and accountability in post-Mubarak Egypt.Her research focuses on transitional justice, including the role of memorialization in social reconstruction; the challenges of teaching history in societies emerging from violent conflict; and trauma. She has also worked at the Ford Foundation as a program officer in New York and the MENA representative based in Cairo, and served as a vice president of the United States Institute of Peace. Barsalou's publications include contributions to Middle East Policy, Jadaliyya, and Memorials in Times of Transition (Intersentia, 2014), and a number of reports published by the Middle East Institute, the US Institute of Peace, and the Goethe Institute.

20 Media and Politics in the Wake of the Arab Uprisings | Summary Report 


\section{Theater or Transitional Justice Reforming the Judiciary in Egypt Sahar Aziz}

This chapter argues that transitional justice did not occur in Egypt following 2011 and stood little chance of occurring for three reasons. First, despite valiant efforts by revolutionary opposition groups that triggered the 25 January uprising, a political transition never materialized; and without a political transition, transitional justice is improbable. Second, a conservative judiciary whose top echelon had been effectively co-opted by Mubarak's centralized executive played a key role in ensuring that no political transition could occur. Finally, the different opposition groups calling for transitional justice, and in effect a political transition, diverged in their expectations of what that entailed. Revolutionary groups including youth activists, labor activists, and progressives called for thick rule of law that would overhaul the legal system substantively, rather than only procedurally. As they chanted "The people want the fall of the regime," they demanded that government affirmatively improve the lives of Egyptians through distributive justice. In contrast, established secular liberal opposition groups and the Muslim Brotherhood $(\mathrm{MB})$ were satisfied with establishing thin rule of law that enforced procedural protections against everyone, including the political elite. The established opposition was focused on reforming the existing legal system rather than developing new structures to redress decades of political suppression and corruption. In the end, transitional justice proved elusive, denying many Egyptians a remedy for decades of tyranny under Mubarak.

Discussions on transitional justice in Egypt presuppose a political transition. More than three years after Egypt's historic 25 January uprising, nothing may be farther from the truth. In turn, this chapter focuses on the period between the 25 January uprising and Fall 2014 to examine why the judiciary impeded the political transition that is the prerequisite to transitional justice. Although Egypt's judiciary has been historically more independent than other state institutions, the circumscribed independence it fought to attain was stunted over the past decade due to the purposeful efforts of the Mubarak regime to counter a nascent judicial independence movement that reached its zenith in 2006. Whether by packing the court with police academy graduates trained to be loyal to the executive branch, employing carrot and sticks tactics to discipline independent-minded judges while rewarding compliant ones, or entrenching judges into a corrupt patronage system that sustained the authoritarian state, Mubarak's regime created a judiciary incapable of delivering transitional justice to the millions of Egyptians who have been tortured, imprisoned, and denied basic social and economic rights for decades. Even worse, members of the senior judicial leadership were either actively quashing the revolutionary forces or passively preventing a meaningful political transition from taking place.

In analyzing why the courts failed to hold Mubarak-era officials accountable, I begin by examining rule of law as a contested concept whose definition depends on the proponent's ideological leanings. The common fault line lies between proponents of thin and thick rule of law. Thin rule of law emphasizes procedural legal mechanisms and procedural due process as sufficient for producing transitional justice. Thick rule of law, by contrast, goes beyond procedural mechanisms to focus on producing substantive equality within a political system that is not necessarily liberal or capitalist. Whether a country pursues thin or thick rule of law affects the types of transitional justice tools it adopts, such as reparations, truth and reconciliation commissions, amnesty, and criminal prosecutions. It also determines the broader political and socioeconomic outcomes sought in the pursuit of transitional justice. 
Then,I proceed to describe the restraints on Egypt's judiciary leading up to 25 January, which contributed to its circumspect stance toward the uprising. The executive branch had installed various structural mechanisms to restrain the judicial leadership from being led by judges acculturated and empowered to uphold the law irrespective of its impact on the executive's power. Indeed, independent adjudication entailed prohibitively high costs to a judge's professional and personal life, including unfavorable judicial appointments, disparate disciplining and transfers, and denials of certain promotions. The Judicial Authority Law of 1972 (JAL) that governs the judiciary, coupled with informal coercive tactics, incentivize judicial self-censorship and voluntary compliance with executive branch expectations.

Finally, I examine how Egypt's judiciary impeded the transitional process through its cooperation with the Supreme Council for the Armed Forces (SCAF) and defiance of Morsi. Specifically, the SCAF's constitutional declarations and executive decrees were consistently upheld as lawful, while the Morsi regime's actions were heavily scrutinized by a skeptical judiciary with an apparently obstructionist agenda. Indeed, the Supreme Constitutional Court issued decisions clearly aimed at handicapping a president from the long-distrusted Muslim Brotherhood. Although the judiciary is not monolithic, a sufficient number of judges at the helm of a centralized governance structure, coupled with a powerful and politicized prosecutor general, had vested interests in cooperating with the military-security apparatus to sabotage the young revolutionaries' reform efforts and prevent any systemic restructuring of the political and economic system. While it is clear that the 25 January revolutionary moment was stillborn, it remains to be seen whether Egypt's judiciary can be rejuvenated into a meaningfully independent institution, able to keep an over-reaching executive from perpetrating another protracted era of authoritarianism.

Sahar Aziz is Professor of Law at Texas A\&M University. She previously taught national security and civil rights law as an adjunct professor at the Georgetown University Law Center. In addition to practicing law, Aziz has also served as a senior policy advisor for the Office for Civil Rights and Civil Liberties at the US Department of Homeland Security where she worked on law and policy at the intersection of national security and civil rights, which remains the focus of her scholarship in the context of the post-9/11 era. She writes, among other topics, on rule of law and democracy in Egypt including gender rights, transparency laws, and election laws. Aziz has regularly published articles with such scholarly journals as Michigan Journal of Race and Law, Harvard National Security Journal, The Middle East Institute, United States Institute of Peace, and George Washington International Review. She earned her JD and MA in Middle Eastern Studies from the University of Texas. 


\section{Security Sector Reform and Transitional Justice after the Arab-Majority Uprisings: The Case of Egypt Omar Ashour and Sherif Mohyeldeen}

The "Arab-majority uprisings" were principally sparked by the brutality of the security sectors in the countries where they occurred. In Tunisia, Mohammed Bouazizi's self-immolation, following an insult by a policewoman in December 2010, triggered the uprising. In Egypt, the June 2010 murder of internet activist Khaled Said by two policemen, followed by state-perpetrated violence during the fraudulent parliamentary elections of NovemberDecember 2010, set the uprising's context. In Libya, the arrest in February 2011 of Fathy Terbil-a human rights lawyer who had represented the families of the victims of the June 1996 Abu Selim prison massacre, in which more than 1,236 political prisoners were gunned down by Muammar Qaddafi's security forces—sparked that country's armed revolution. In Syria, abuses committed in March 2011 by Assad's security forces, which included the use of extreme violence against children and teenagers in Deraa, triggered the protests that ignited that country's ongoing armed uprising. In many ways, the Arab-majority uprisings were a region-wide reaction that was sparked by the violations committed by the security services and a quest for holding them accountable. In the background, other variables were at play, including socioeconomic inequalities, deprivation, and repressive authoritarianism and limited political freedoms.

Throughout the decades prior to the 2011 revolutions, many Arab security establishments behaved more like organized crime syndicates than professional security services. Concepts such as transitional justice, human rights, human security, democratic control, elected civilian oversight, and accountability were absent from the lexicons of Arab interior and defense ministries, and any attempts to introduce them meaningfully were met with repression. Egyptian activists unsurprisingly chose to stage the protests that initiated Egypt's uprising on 25 January, Egypt's National "Police Day," a state holiday intended to honor the security services.

But the confrontation with the security services did not end after toppling Mubarak on February 11, 2011. Activists realized that the regime had deeper roots. By March 2011 the accumulated grievances and legacy of brutality led to another confrontation between the pro-revolution forces and parts of the security sector, this time directly with the State Security Investigations (SSI), the feared domestic intelligence services. On the evening of March 5, 2011, thousands of Egyptian protesters stormed a few of the SSI headquarters. Secret graveyards, medieval-like dungeons, files of political dissidents held for more than two decades, names of judges who helped fix elections and lists of informants—celebrities, religious figures, talk-show hosts, and opposition leaders—were all captured on camera and uploaded onto popular websites. Torture rooms and equipment were captured on camera in every SSI building stormed by protesters. For average Egyptians, the sheer volume and graphic details of the released files were shocking. Although the unlawful detentions, kidnappings, disappearances, systematic torture and rape perpetrated by the regime and its security forces have been documented over the last three decades, by both local and international human rights organizations, most media outlets would avoid addressing those taboos while Mubarak ruled and even afterwards.

As a result, security sector reform and transitional justice became immediate objectives of most revolutionary and reformist forces, regardless of ideological or political affiliation. Between 2011 and 2013, activists, scholars, parliamentarians, officials, non-governmental organizations (NGOs), and international governmental organizations (IGOs) proposed several initiatives aiming at security sector reform (SSR) and transitional justice 
(TJ). In early 2013, a five-phase, ten-year-long proposal was submitted to the Presidential Adviser on Security Issues, General Emad Hussein, and the National Security and Foreign Affairs Committee of the Egyptian Upper House (Consultative Council), which is partly composed of retired army and police officers, among other parliamentarians. None of these initiatives reached an execution stage, due to various political, institutional, and bureaucratic hurdles. Following the military coup of July 2013, the probability of implementing any transitional justice or security sector reform initiatives became almost negligible. The political will and material interests of the new military-dominated regime have not reconciled yet with reform processes. This was reflected in a widely disseminated lecture by General Abdel-Fattah el-Sisi to army commanders.

Despite the gravity of the security violations and the intensity of the pro-democracy efforts, the January uprising in Egypt failed to bring about successful security sector reform and transitional justice processes. The question is "why." This chapter takes an overview of some of the important TJ and SSR initiatives following the January uprising and attempts to explain the reasons behind their failure. It starts with a historical overview of the crises of transitional justice and the security sector in Egypt. It then analyzes the TJ and SSR proposed initiatives during the period 2011-13, and the reasons behind their failures. The chapter concludes with the ramifications of the failure of SSR processes, mainly in the case of Egypt.

Omar Ashour is Senior Lecturer in Security Studies and Middle East Politics and Director of Doctoral Studies at the University of Exeter. His research interests include: asymmetric warfare, insurgency and counterinsurgency, Islamist movements and ideologies, democratization (with focus on security sector reform and civil-military relations), security, terrorism, and strategic military studies. His published works cover the Middle East, North Africa, the Caucasus, Central Asia, and Arab and Muslim communities in the West. His publications appeared in Foreign Affairs, Terrorism and Political Violence, International Affairs, Studies in Conflict and Terrorism, Middle East Journal, Canadian Journal of Political Science, Journal of Conflict Studies, and others. He received his MA at the American University in Cairo and his $\mathrm{PhD}$ from McGill University.

Sherif Mohyeldeen is a researcher and coordinator on counter terrorism and human rights at the Egyptian Initiative for Personal Rights. He is finishing his MA in Political Science at Cairo University. He also headed the Political Department of the Civilized Change Project, and the coordinator of Transitional Justice and Security Sector Reform at United Group attorney organization. He has also worked at many leading Egyptian think tanks and research centers such as House of Wisdom for strategic studies, and the Nile Center for Economic Studies. His research interests are security sector reform, revolution and democratic transition, NGOs, and social movements studies.

24 Transitional Justice in the Middle East and North Africa | Summary Report 


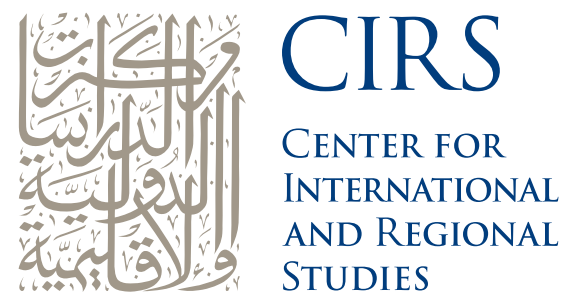

GEORGETOWN UNIVERSITY SCHOOL OF FOREIGN SERVICE IN QATAR 


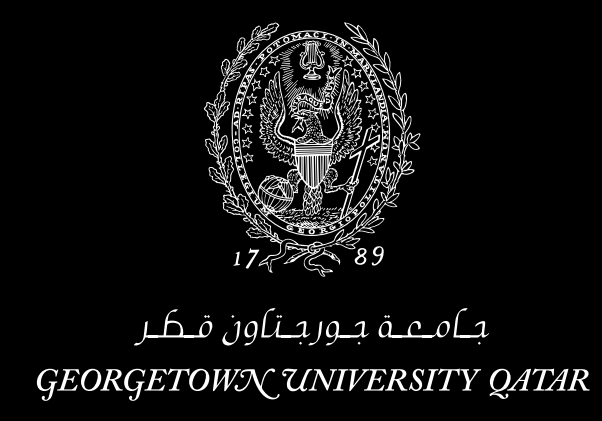

Center for International and Regional Studies

P. O. Box 23689, Qatar Foundation

Doha, State of Qatar

(C) 2017

http://cirs.georgetown.edu cirsresearch@georgetown.edu

Tel +97444578400

$\mathrm{Fax}+97444578401$ 